技術報告

\title{
石油系燃料油污染土堙のバイオレメディエーション 一特に環境微生物学的なアプローチー
}

\author{
北山 茂一 ${ }^{*} \cdot$ 原 宏哉* 岩城 美朝**. 長里 千香子*** \\ 本村 泰三 $* * *$ 遠山 忠 ${ }^{* * * *}$. 張 傛喆 $* * * *$. 菊池 慎太郎 $* * * *$
}

\section{要旨}

近年，省エネルギー的な污染浄化技術としてバイオレメディエーション法が注目されているが，この方法 は微生物の污染原因有機物代謝活性に依存するため処理完了までに長期間を要するのが一般的であり，ある いは実用のための微生物的安全性についての検討が不十分とも指摘されている，我々は，石油系燃料油と重 金属類で重度に污染された土壤から, 灯油を唯一炭素源として良好に増殖するPseudomonas aeruginosaの 2 株を分離し，マウスを用いる慢性毒性ならびに急性毒性試験からこれらの微生物を屋外で用いることの安 全性を確認した。これらの菌を混合し, 従来の石油系燃料油のバイオレメデイエーション法に用いられた菌 濃度 $\left(10^{10} \mathrm{cfu} / \mathrm{m} \ell\right)$ よりもはるかに低い濃度 $\left(10^{2} \mathrm{cfu} / \mathrm{m} \ell\right)$ で地表あるいは地表近くに直接的に散布したと ころ，わずか 1 カ月の処理期間で約 $70 \% の$ 污染を浄化することが可能であった.

キーワード : バイオレメデイエーション, 石油系燃料油資化微生物, 微生物的安全性

\section{はじめに}

ガソリンや灯油などの石油系燃料油は今日の経済活 動と社会生活に不可欠なエネルギー源であり，その消 費量も年々増加しつつあるが，同時にガソリンスタン ドなどの小規模事業所跡地に残存するガソリンや, 北 海道のような寒冷地における一般家庭灯油備蓄設備か らの灯油漏出に起因する土壤污染も顕在化しつつある.

そのような観点から, 微生物を利用して省エネル ギー的に污染土壌を浄化し得るバイオレメディエー ション法（原位置微生物土壤浄化法）が注目されてお り, 土壤内在微生物に栄養源を供給して污染原因有機 物を分解除去するバイオスティミュレーション法や, 污染原因有機物に特異的な分解能力を有する微生物 （污染原因物質資化微生物）を利用するバイオオーグ
メンテーション法などの改良法も開発されている ${ }^{1,2)}$.

他方, バイオレメディエーション法による污染浄化 は微生物の污染原因有機物代謝活性（分解能力）に依 存することから, 処理には数カ月から数年の長期間を 要するのが一般的であり，期間の短縮（効率化）を目 的として極めて高濃度の特定物質資化菌種を利用する ことも試みられている。たとえば久保らは, 高密度培 養法によって調製した $10^{10} \mathrm{cfu} / \mathrm{m} \ell の$ 培養液を浄化対象 土壤に投与して土壤微生物濃度を $10^{8} \mathrm{cfu} / \mathrm{g}-$ 土壤に保 持することにより石油污染土壤の浄化が効率化された と報告している ${ }^{2)}$.

しかし特定の菌種を人為的に高濃度で用いることは 土壤の菌叢を破壊して結果的に土畩活性を低下させる 場合もあり，あるいは低濃度では人体に無害な菌種で あっても高濃度では有害性の発現する危険性も懸念さ

Bioremediation of Soils Contaminated with Petroleum Oils

- Environmental and Microbiological Approaches -

2008年11月10日受付

*(株アールアンドイー Shigekazu KITAYAMA, Hiroya HARA

2009年 2 月 10 日受理

**とりりおん北海道協同組合 Yoshitomo IWAKI

***北海道大学北方圈フィールド科学センター水圈ステーション Chikako NAGASATO, Taizo MOTOMURA

$* * * *$ 室蘭工業大学大学院工学研究科 Tadashi TOYAMA, Young Cheol CHANG, Shintaro KIKUCHI 
れることから ${ }^{3,4)}$, 微生物疫学的には低濃度菌を用い るバイオレメデイエーション法の実施が望まれる.

また浄化対象とする土壤には，重金属類に代表され るような微生物の有機物代謝活性に抑制的あるいは阻 害的に作用する因子が高濃度で存在する場合もあり， 実験室における試験成果をそのまま実地に適用しても 浄化効果が発現しない場合も多い.

我々は，石油系燃料油と重金属で重度に污染された 土壤から石油系燃料油を唯一の炭素源として良好に増 殖する 2 種類の細菌類を分離し，その微生物的安全性

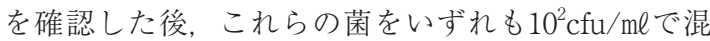
合した菌懸濁液を石油系燃料油污染土壤表面あるいは 表面付近に直接的に散布することにより，最大で当初 濃度の約 $70 \%$ に相当する污染を 1 カ月間で浄化したの で紹介する。

\section{1．石油系燃料油分解菌の分離と培養}

石油系燃料油を大量に使用する工場構内の土壤か ら，石油系燃料油を唯一炭素源として増殖する微生物 の分離を試みた。なお一般に，土壤 $1 \mathrm{~kg}$ 当たりに数十 $\mathrm{mg}$ 程度の重金属が存在しても, 微生物はメタロチオネ インに代表される重金属結合タンパク質を誘導合成し て細胞内重金属濃度の恒常性を保ち, 増殖と有機物代 謝が可能であるが, 過剰な重金属の存在下では呼吸系 などの酸化還元系が阻害され，あるいは細胞外殼構造 に小孔が形成されて細胞内容物が漏出するため死滅す $る^{5-7)}$. 他方，表 1 に示すように，微生物分離に用い た土壤には高濃度の重金属が含有されていたことか ら,この土壤中に存在する微生物は重金属に対して耐 性をもつことが期待される。

具体的には, 工場内の数カ所から採取した土䁃の約 $1 \mathrm{~g}$ を表 2 に示す灯油 - 最少塩類液体培地（oilminimum salts liquid medium : oil-MS 液体培地）に 分散して好気的に培養した後, その培養液を寒天で固

表 1 石油系燃料油資化微生物の分離に用いた土壌 中の重金属*

\begin{tabular}{|c|c|c|c|c|c|}
\hline \multirow{2}{*}{ 採取点 } & 鉄 & マンガン & 銅 & 鉛 & 亜 鉛 \\
\hline & \multicolumn{5}{|c|}{$(\mathrm{mg} / \mathrm{kg} \cdot$ 土壤 $)$} \\
\hline A & 300 & 150 & 123 & 29.1 & 0.91 \\
\hline B & 546 & 98 & 42 & 10.8 & 0.55 \\
\hline $\mathrm{C}$ & 911 & 54 & 66 & 7.2 & 13 \\
\hline $\mathrm{D}$ & 1,010 & 27 & 97 & 30.2 & 5.12 \\
\hline
\end{tabular}

*重金属の測定は ICP 発光分析法によって行った.
表 2 灯油一最少塩類液体培地 $1 \ell$ 当たりの組成*

\begin{tabular}{|c|c|}
\hline 物 質 & $\begin{array}{l}1 \text { l当たりの } \\
\text { 重量など }\end{array}$ \\
\hline$\left(\mathrm{NH}_{4}\right)_{2} \mathrm{SO}_{4}$ & $1.0 \mathrm{~g}$ \\
\hline $\mathrm{K}_{2} \mathrm{HPO}_{4}$ & $1.0 \mathrm{~g}$ \\
\hline $\mathrm{NaH}_{2} \mathrm{PO}_{4}$ & $0.2 \mathrm{~g}$ \\
\hline $\mathrm{NaCl}$ & $0.05 \mathrm{~g}$ \\
\hline $\mathrm{MgSO}_{4} \cdot 7 \mathrm{H}_{2} \mathrm{O}$ & $0.2 \mathrm{~g}$ \\
\hline $\mathrm{CaCl}_{2}$ & $0.05 \mathrm{mg}$ \\
\hline $\mathrm{FeCl}_{3} \cdot 6 \mathrm{H}_{2} \mathrm{O}$ & $8.3 \mathrm{mg}$ \\
\hline $\mathrm{MnCl}_{2} \cdot 4 \mathrm{H}_{2} \mathrm{O}$ & $1.4 \mathrm{mg}$ \\
\hline $\mathrm{NaMoO}_{4} \cdot 2 \mathrm{H}_{2} \mathrm{O}$ & $1.17 \mathrm{mg}$ \\
\hline $\mathrm{ZnCl}_{2}$ & $1.0 \mathrm{mg}$ \\
\hline 市販灯油** & $10 \mathrm{ml}$ \\
\hline \multicolumn{2}{|c|}{ 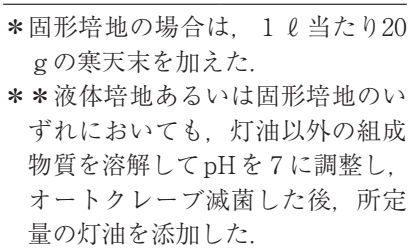 } \\
\hline
\end{tabular}

化した oil-MS 液体培地（oil-MS 固形培地）表面に塗 布接種した。その結果, 固形培地に扔いても灯油を唯 一炭素源として良好に増殖し、コロニーを形成する微 生物 2 株を分離した（写真 1 ）。な扮写真 1 （a）に 示すように，分離菌株の 1 株のコロニーは滑面で光沢 があってコロニー周囲は明瞭であり，他の 1 株のそれ は粗面で光沢がなくコロニー周囲は不明瞭であったこ とから，両者を明瞭に区別することが可能であった．

これら分離菌それぞれの rRNAを微生物科学的常 法にしたがって抽出して PCR 法で増幅した後, 日本 DNA データバンク (DDBJ ; DNA Data Bank of Japan, http://www.ddbj.nig.ac.jp）に登録されている 微生物の rRNA との相同性を比較し, これらの分離 菌株のいずれもPseudomonas aeruginosaの菌株と同 定した，以下に扔いては，これらをそれぞれ $P$. aeruginosa TW-1株あるいはP. aeruginosa TW-2株 と呼ぶ.

P. aeruginosa $\mathrm{TW}-1$ 株および TW-2株のいずれも, ペプトン，酵母エキスおよび塩化ナトリウムを主成分 とする LB（Luria-Bertani）培地などの調製が容易な 一般的培地や，ジャガイモ澱粉搾澾などの農産廃棄物 を利用する安価な培地 ${ }^{8,9)}$ でも良好に増殖し，さらに これらの培地から石油系燃料油を唯一炭素源とする oil-MS 培地に移しても遅滞期なくただちに増殖する ことが特徵である。炭素源や窒素源が異なる培地に微 


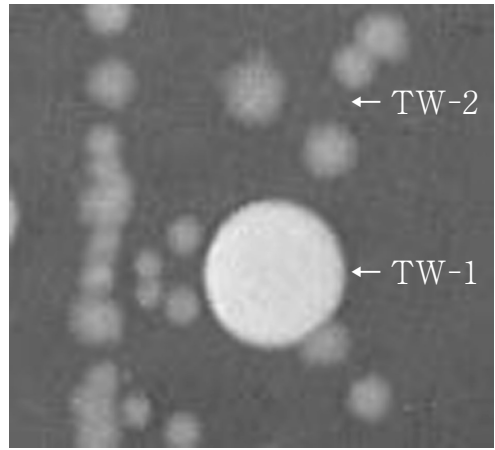

(a)

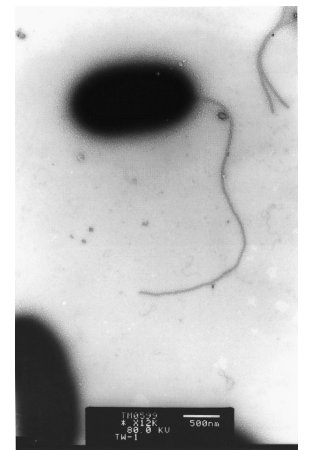

(b)

写真 1 石油系資化細菌の形態

（a）oil-MS 固形培地の TW-1株㧍よび TW-2株のコロニー。（b） TW-1 株の電子顕微鏡写真 (倍率10,000倍)。な扮 TW-1株㧍よび TW-2株はい ずれも, 長軸1.3 $1.5 \mu \mathrm{m}$, 短軸 $0.5 \sim 0.7 \mu \mathrm{m}$ の桿菌で鞭毛を有する.

生物を移植して培養すると, 新たな栄養源に適応する 酵素系の誘導などの現象がもたらされるために見かけ の生菌数が変化しない遅滞期が観察される場合も多 い. 他方, 微生物が広い栄養要求性と新たな栄養源に 対する高い資化性を有する場合には構成タンパク質系 （構成酵素系）による物質代謝が可能であるので適応 現象が不要であり，遅滞期は観察されない10-12)。した がってTW-1株㧍よびTW-2株を，天然有機物を栄養 源とする培地から石油系燃料油を唯一炭素源とする培 地に移して培養しても遅滞期が観察されない事実は, これらの菌が高い石油系燃料油資化性を有することを 示唆するものである.

\section{2. 分離菌の安全性評価}

本菌は，ガソリンスタンド跡地のような小規模事業 所跡地などの石油系燃料油污染土壤の微生物的浄化へ の利用を目的とすることから，最終的には屋外開放系 での使用態様が想定され，微生物的安全性が保証され なければならない.

このためマウスを被検動物として本菌の長期毒性拐 よび急性毒性について検討した。長期毒性は，TW-1 株抢よび TW-2株を混入した慨（約 $10 \mathrm{cfu} / \mathrm{g}$-慨）を マウスに投与し，また急性毒性は，これらの菌株を懸 濁した生理食塩水 $0.2 \mathrm{~m} \ell （$ 約 $5 \times 10 \mathrm{cfu}$ に相当）をマウ ス腹腔に注入して調べた（写真２）。前者においては 1 カ月間にわたる試験に拀いても対象群（TW-1株お よび TW-2株を投与していない群）との間に有意な体 重変化や脱毛などの病態は観察されず，また被検マウ 久を解剖して血液や肝臓, 胃などの臟器の生化学検査

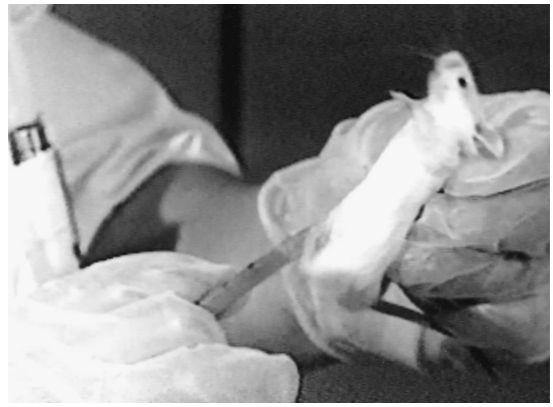

写真 2 分離菌の急性毒性試験

を行ったが ${ }^{13)}$ ，対象群に比較して炎症発生や酵素活性 変化は認められなかった。ささらに後者においては菌懸 濁液注入による被検マウスの死亡はなかった。以上か ら，本菌株を屋外などの開放系において用いることの 安全性が確認された。

\section{3．実験室における石油系燃料油の浄化試験}

ついで，園芸黒土（主成分：北海道十勝産天然土, $\mathrm{pH}$ 中性：森産業(株) (北海道士幌町)）を人為的に灯 油で污染して実験室規模の污染モデル系を作成し，本 菌による浄化試験を試みた。

すなわち，あらかじめオートクレーブで内在性微生 物を滅菌した約 $10 \mathrm{~kg}$ の園芸黒土に約 $0.2 \% （ \mathrm{v} / \mathrm{w} ） の$ 市販灯油，ならびにいずれも重金属濃度として $300 \mathrm{mg}$ $/ \mathrm{kg}$ 一土畩に相当する塩化亜鉛 $\left(\mathrm{ZnCl}_{2}\right)$, 塩化鉄 $\left(\mathrm{FeCl}_{2}\right.$ ・ $\left.6 \mathrm{H}_{2} \mathrm{O}\right)$ ，および硫酸銅 $\left(\mathrm{CuSO}_{4} \cdot 5 \mathrm{H}_{2} \mathrm{O}\right)$ の水溶液を添 加して攪拌し，モデル污染土壤（被検土）とした。こ れに LB 培地で一夜培養した TW-1株および TW-2株 


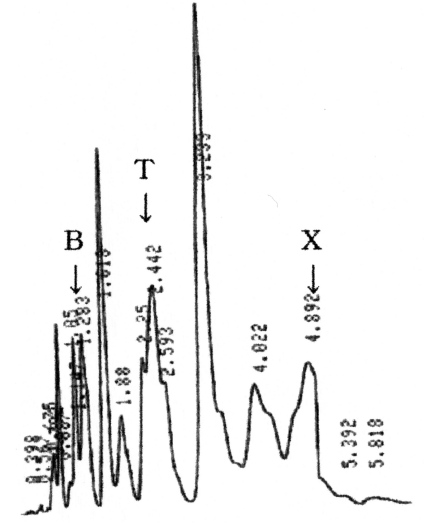

(a)

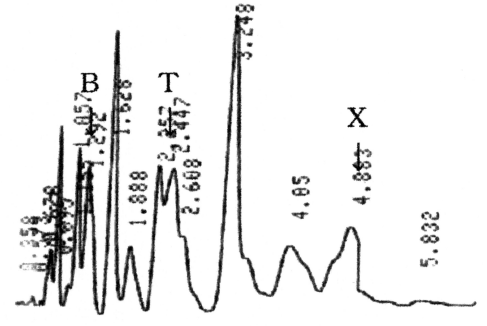

(b)

図 1 ヘッドスペースーFID ガスクロマトグラム

処理期間：(a) 0 日間，(b) 14日間， B，TあるいはXはそれぞれ，ベンゼン（保持時 間1.2分), トルエン (2.4分), あるいはキシレン (4.8分) のピークを示す. GC： Shimadzu GC2014, 樹脂： shincrom F51+ bentone 34, インジェクター温度抒よびディ テクター温度 : $140^{\circ} \mathrm{C}$, カラム温度 : $60^{\circ} \mathrm{C}$.

の混合懸濁液を $10^{3} \mathrm{cfu} / \mathrm{kg}$ - 被検土となるように散布し て攪拌し，アルミホイルで覆って $28^{\circ} \mathrm{C} に$ に保持した。所 定の期間後に約 $10 \mathrm{~g}$ の被検土を採取して公定法 ${ }^{14)} に$ したがってヘッドスペース法－FID ガスクロマトグ ラフィ法で分析し, クロマトグラムにおけるピーク総 面積の減少から残存灯油量を測定した。

図1にクロマトグラムの例を示した。クロマトグラ ムのピーク面積の総和は処理日数の経過にともなって 減少し，また保持時間3.2分に検出される未同定物質 のピーク面積, およびトルエン(保持時間2.4分)のピー ク面積の減少が顕著であった。

また図 2 に経日的測定結果をまとめたが, 試験開始 後 2 週間で残存灯油濃度は速やかに減少し, その後 2 週間は初期濃度の約 $50 \%$ （対照系における揮発などの 自然減少を差し引いた実質減少は約60\%）にまで緩や かに減少して 4 週以降は定常状態となった. 以上の結 果は, 低濃度の TW-1株㧍よびTW-2株が重金属を含 有する土壤中に扔いても高い灯油資化活性，すなわち 浄化活性を発現することを示すものである.

なおデー夕は示さないが, 土畩に存在する総菌数を 寒天平板法で調べたところ, コロニー数から推定され る菌数は試験開始直後から緩やかに減少しはじめ, 試 験開始 4 週後には10cfu/10g-被検土以下であった。 この結果は石油系燃料油污染土壤において微生物総数 は急激に減少するという報告 ${ }^{2}$ と一致するものであ り, またその理由は不明であるものの, 灯油分解菌で ある TW-1株掞よび TW-2株の菌数も石油系燃料油污

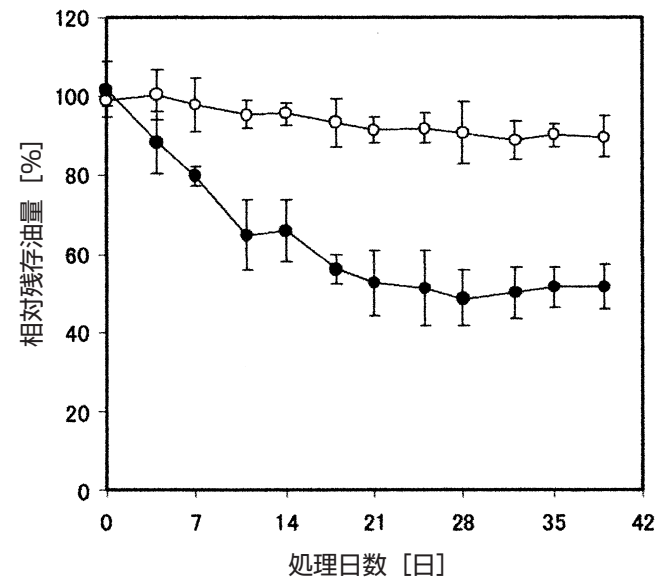

図 2 実験室規模における石油系燃料油の浄化 初期石油系燃料油濃度（約 $2 \%, v / w ） を 100 \%$ と, 処 理後に残存する濃度の相対量を示した。いずれの系も 5 回 の測定に扮ける平均値を, ○(対照系：分離菌を投与して いない系）あるいは (実験系：分離菌を投与した系）と して示し，またエラーバーは95\%信頼区間を示す.

染土壤中で減少することを示すものである。したがっ て TW-1株扔よびTW-2株の生菌数が減少した時点で これらの菌を追加投与するなら, さらに浄化反応が進 行することも示唆される.

\section{4. 屋外における試験}

ついで屋外に試験槽（強化プラスチック製，横：3.6 $\mathrm{m} \times$ 縦 : $1.5 \mathrm{~m} \times$ 高さ : $1.5 \mathrm{~m})$ を設置し, 約 $1 \mathrm{~m}$ の厚 さに土（被検土）を入れた後, 被検土の約 $0.2 \%(\mathrm{v} / \mathrm{w})$ 
となるように市販灯油を表面に散布し，50cmの厚さに 覆土した（図 3，打よび写真 3)。な扮被検土抢よび 覆土は，試験槽を設置した箇所（十数年間にわたって 使用していない空地）の表土をオートクレーブ滅菌せ ずに用いたが，73mg-亜鉛／kg-表土，187mg-鉄／kg， および $88 \mathrm{mg}$ - 銅 $/ \mathrm{kg}$ を含有していた。試験は平成18年 6 月末から 7 月末まで行い, この間の平均外気温は

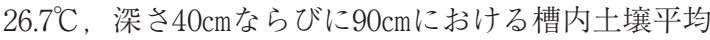

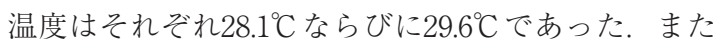
降雨の影響を除外するため, 試験槽をシートで覆った。

また予備試験の結果， 2 週後には散布灯油の沈下は

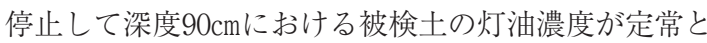
なった。この結果から, 試験槽に灯油を散布した後の 2 週は放置し, その後, 覆土表面に TW-1株と TW-2 株の混合培養液（約 $10^{3} \mathrm{cfu} / \mathrm{kg}^{-}$土壤に相当）を散布し た.

所定の期間後, 簡易ボーリングして梁度 $90 \mathrm{~cm}$ 土畩 を採取し，前述のヘッドスペース法と FID ガスクロマ トグラフィ法で分析した，その結果を図４に示したが, TW-1株と TW-2株の混合培養液を散布した後 3 週間

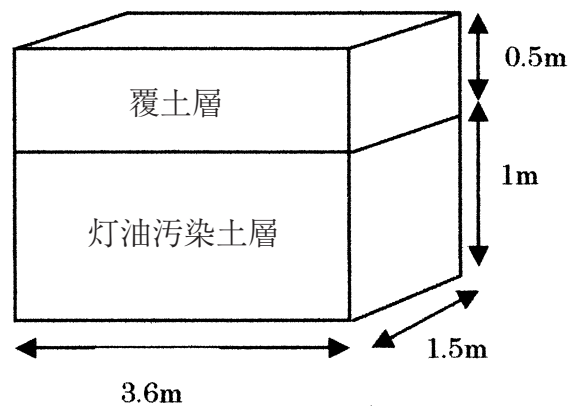

図 3 屋外実証試験槽の概要

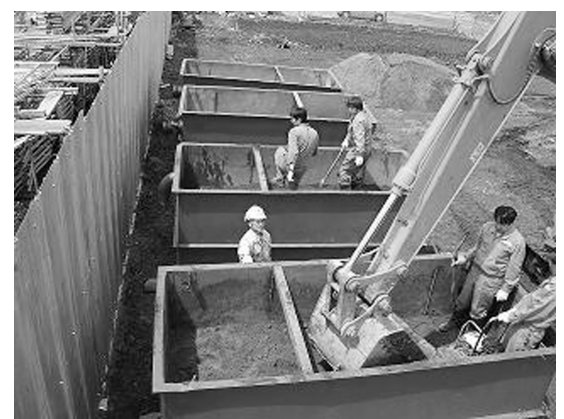

(a)

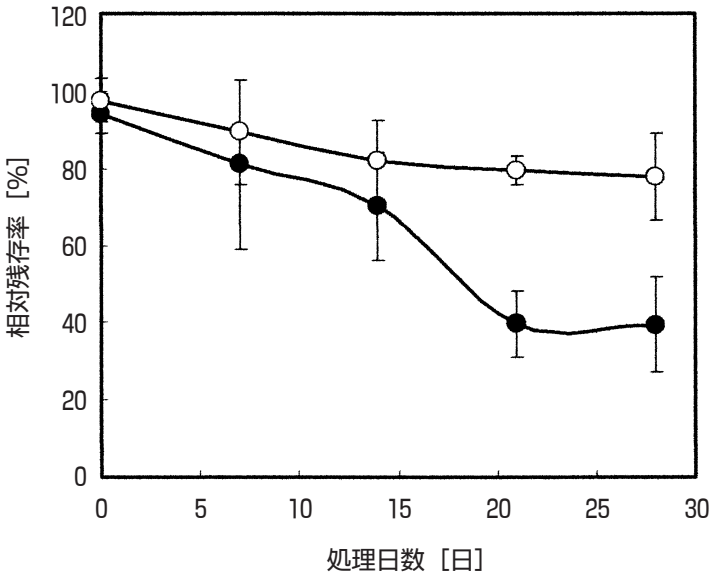

図 4 屋外における石油系燃料油の浄化 初期石油系燃料油濃度（約 $2 \%, v / \mathrm{w} ）$ を $100 \%$ とし，处理後に 残存する濃度の相対量を示した。いずれの系も 5 回の測定にお ける平均值を○(対照系) あるいは (実験系) として示し， またエラーバーは $95 \%$ 信頼区間を示す。

で残存灯油量は初期灯油量の約 40\%（対照系の自然減 少を差し引いた実質減少は約60\%）にまで減少した

\section{5. 実地 試 験}

前記の試験結果からすれば，分離した 2 菌株を污染 が存在する個所の表土あるいは表土近くに直接的に散 布することによって短期間に污染を浄化することが期 待される。

以上から, 本法による污染浄化の実地試験を行った. すなわち梁度 $1 \mathrm{~m} \sim 3 \mathrm{~m}$ の土中に $2 \sim 7 \mathrm{~m}$ にわたる石 油系燃料油（ガソリンと灯油）污染が複数のポイント として存在する北海道内小規模事業所跡地を実地試験 地として選択した（図５）。それぞれの污染ポイント の表土約 $50 \mathrm{~cm}$ を重機で機械的に除き，TW-1株および

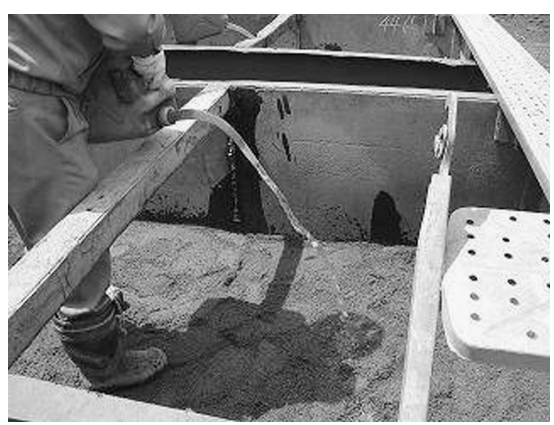

(b)

写真 3 屋外実証試験槽の構築

（a）試験槽への被検土の搬入，（b）灯油散布による人為的污染土の作成. 


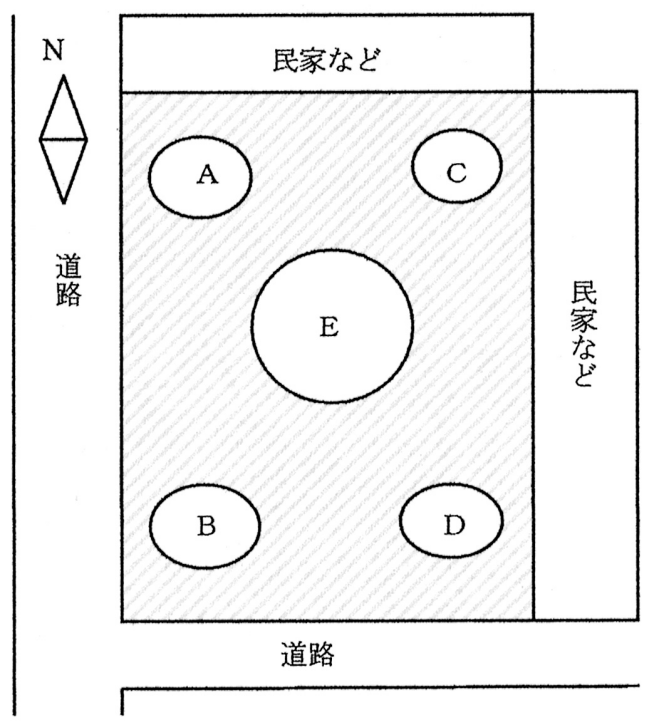

図 5 実地試験地の概略

実地試験地は石油系燃料油を大量に使用していた北海道内 の小規模事業所跡地 (斜線部, 約 $750 \mathrm{~m}^{2}$ ) で, 隣接する民家 などとの間はコンクリート塀で仕切られている，図中のア ルファベットの箇所は予備調査で石油系燃料油污染が明ら かになったことから，TW-1株抢よびTW-2株を散布した 箇所を示す.

$\mathrm{TW}-2$ 株の混合培養液（ $10^{2} \mathrm{cfu} / \mathrm{m} \ell-\mathrm{MS}$ 培地）を $500 \mathrm{~m} \ell$ $/ \mathrm{m}^{2}$ で散布した後, 先に取り除いた表土で覆土した(写 真 4 )。なお試験期間中（平成19年 7 月 1 日から 8 月 2 日）の合計降水量は $24 \mathrm{~mm}$ であり, また平均気温は $28.1^{\circ} \mathrm{C}$, 深さ $50 \mathrm{~cm}$ 平均土温は $26.9^{\circ} \mathrm{C}$ であった。 また

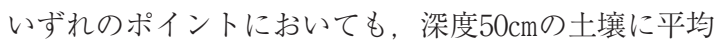
$150 \mathrm{mg} / \mathrm{kg}$ の鉄が存在した.

試験結果を表 3 に示したが, 菌液散布33日後には最 大で約70\%の浄化が可能であった。 なお，この試験 においては対照区（菌を投与していない区）の設置が
表 3 実地試験結果

\begin{tabular}{|c|c|c|c|c|}
\hline \multirow{2}{*}{$\begin{array}{l}\text { ポイ } \\
\text { ント }\end{array}$} & \multirow{2}{*}{$\begin{array}{c}\text { 試料採取 } \\
\text { の深さ } \\
(\mathrm{cm})\end{array}$} & \multicolumn{2}{|c|}{ 相対的石油系燃料油濃度* } & \multirow{2}{*}{$\begin{array}{l}\text { 浄化率** } \\
(\%)\end{array}$} \\
\hline & & 処理前 & 処理後 & \\
\hline A & 50 & 1,200 & 890 & 25.8 \\
\hline B & 50 & 620 & 520 & 16.1 \\
\hline $\mathrm{C}$ & 50 & 1,010 & 810 & 19.8 \\
\hline D & 50 & 1,100 & 870 & 20.9 \\
\hline $\mathrm{E}$ & 50 & 750 & 710 & 5.3 \\
\hline $\mathrm{E}$ & 100 & 630 & 350 & 44.4 \\
\hline $\mathrm{E}$ & 150 & 1,800 & 990 & 45.0 \\
\hline $\mathrm{E}$ & 200 & 2,100 & 1,700 & 19.0 \\
\hline $\mathrm{E}$ & 250 & 3,700 & 1,100 & 70.2 \\
\hline $\begin{array}{l}* ヘ ッ \\
* \text { 出現 } \\
* * 10\end{array}$ & \multicolumn{4}{|c|}{$\begin{array}{l}\text { *ヘッドスペース法と FID- ガスクロマトグラフィによって } \\
\text { 出現するピーク面積の総和. }\end{array}$} \\
\hline
\end{tabular}

困難であったので揮発などによる自然減少量が不明で あり，したがって投与菌による実質的浄化率は表 3 に 示す浄化率よりも低值になると推定されるが，図４に 示した実証試験槽における成果を考慮するなら TW-1 株㧍よびTW-2株の有意性が強く示唆される。

\section{おわりに}

本稿で紹介したPseudomonas TW-1株および TW-2株は培養が極めて容易であり，また高濃度の重 金属を含有する土壤であっても污染個所表土あるいは 表土付近に散布する簡便な作業によって1 カ月程度の 処理期間で有意な石油系燃料油浄化効果を挙げられる ことが特徴である。

もとより本法は石油系燃料油で污染された小規模事 業所跡地の浄化を目的に開発された技術であるので大

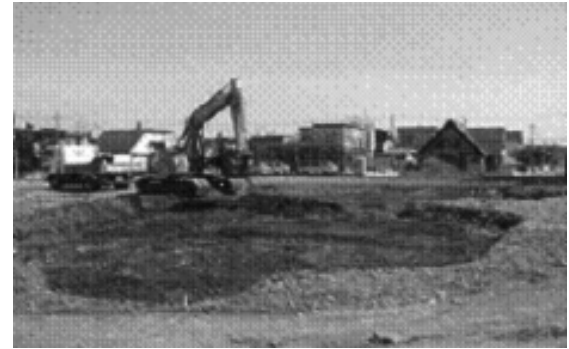

(a)

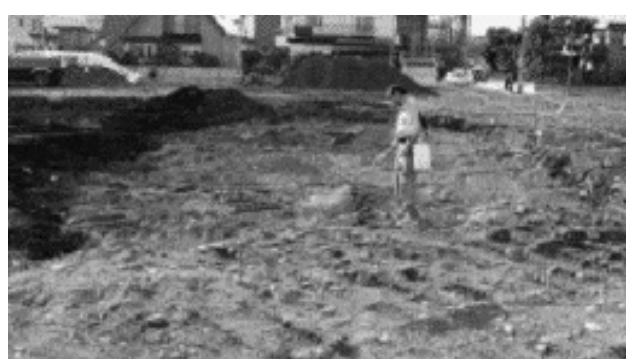

(b)

写真 4 実地試験の様子

（a）予備試験で明らかとなった污染個所の表土を除いた後，（b）TW-1株と TW-2株の混合懸濁液を散布し， さらに除いた土を戻して覆土した。 
規模污染個所に適用できるものではなく，また当該菌 株による石油系燃料油分解機構の生化学的詳細につい ても今後の研究を待たなければならないが, 新たなバ イオレメディエーション法の一例として興味深い.

本研究の一部は，平成16年度(財)北海道科学技術総合 支援センター「微生物を利用する石油系燃料油污染土 壤の浄化」および平成17年度(独)科学技術振興機構 「シーズ育成試験：特異的鉱物油分解菌の探索と土䁃 浄化への応用」に対する研究助成金によって実施した。

\section{文献}

1 ) 菊池慎太郎編著; 微生物工学, 91-102, 三共出版(株), 2004.

2 ) 久保幹; 微生物量調整・維持による石油系污染土壤の高 効率浄化技術, 「土䁃 - 地下水污染の浄化㧍よび修復技 術」，193-205，（株)エヌ・ティーエス， 2008.

3 ) 矢木修身; 生物化学的浄化法による浄化技術, 「土壤 - 地 下水污染の浄化および修復技術」，47-58，(株エヌ・ティ 一エス, 2008

4 ) 青木正和; 非定型抗酸菌症の疫学, 臨床医, 7, (7), 1650-1652, 1981.

5 ) 菊池慎太郎編著; 微生物工学, 23-24, 三共出版(秼), 2004.

6 ) 水谷敦司, 相馬英明, 田中壽晃, 島津昌光, 遠山忠, 張
傛喆, 菊池慎太郎；レーザー照射による抗菌性酸化チ夕 ン材の作成と海洋污損生物付着防除への応用, 環境技術, 35, (10), 756-762, 2004.

7 ) S. Kikuchi, M. Fukumoto, H. Takahashi : Iron Storage in Mycobacterium smegmatis under Iron-sfficient and Ironoverload Conditions, Bioscience, Biotechnology \& Biochemistry, 58, (5), 885-888, 1994.

8 ）水谷敦司, 北山茂一, 原宏哉, 張傛喆, 遠山忠, 長谷川靖, 菊池慎太郎; 光合成細菌による農産廃棄物からの生理活 性物質生産と農業への応用可能性, 水処理技術, 48, (2), 49-54, 2007.

9 ) 水谷敦司, 海野健一, 高橋紀行, 成田均, 永原利雄, 武 者一宏, 藤井克彦, 菊池慎太郎; 微生物を利用する水産 廃棄物の資源化, 水処理技術, 45, (12), 551-555, 2004.

10）菊池慎太郎編著; 微生物工学, 29-35, 三共出版(株), 2004.

11) S. Kikuchi and M. Ishimoto ; A D-Serine Dehydratase Acting also on L-Serine from Klebsiella pneumonia, Journal of Biochemistry, 84, (5), 1133-1138, 1978.

12) S. Kikichi and M. Ishimoto; Nitrate respiration of Klebsiella pneumonia on amino acids, especially on serine, Zeitschrift für Allgemeine Mikrobiologie, २०, (6), 405-413, 1980.

13）山村雄一 ; 病理生化学, 449-520, 岩波書店, 1971.

14）土壤環境センター編；環境省油污染対策ガイドライン, 99-115，化学日報社，2006。

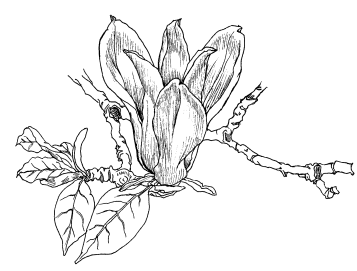

